\title{
EVALUATION OF ENGLISH TEACHING MATERIALS USED AT SD IT UMMI IN KOTA BENGKULU BASED ON KTSP (KURIKULUM TINGKAT SATUAN PENDIDIKAN)
}

\author{
Meri Lestari \\ Syarial \\ Arono \\ University of Bengkulu, Indonesia \\ Merilestari42@yahoo.com
}

\begin{abstract}
The objectives of this study were: (1) To find out whether textbook used by second grade students at SD IT UMMI Kota Bengkulu fulfill the criteria of a good textbook. (2) To find out whether the English textbook used by second grade students at SD IT UMMI Kota Bengkulu relevant to KTSP curriculum. This research used descriptive qualitative content analysis as its research method. The data were collected from the English student book "Let's Make Friends with English" for second grade students. The results showed that English textbook entitled "Let's make friends with English" used by second grade students at SD IT UMMI Kota Bengkulu have fulfilled the criteria of a good textbook by achieving the Fair fulfillment. The textbook was categorized relevance to the KTSP curriculum, but the activities in the listening can be said irrelevant because they cannot cover the learning objectives in listening. It was then recommended that the teachers need to modify the tasks and activities on the textbook which did not fulfill the criteria of good textbook, especially in the area of accompanying materials (CD, Cassettes and pictures), language skill, and teach ability aspects.
\end{abstract}

Key words: Evaluation, English teaching materials, and KTSP

\section{INTRODUCTION}

In Indonesia, the Government determines national policy and education standards to guarantee the quality of national education which sets in legislation the national education system (UUD Sisdiknas pasal 50 ayat 2). Furthermore, KTSP (Kurikulum Tingkat Satuan Pendidikan) is very appropriate for student needs, circumstances, and conditions of the school. Thus, the school has enough authority to design and specify the materials, activities, media, and assessment.

In KTSP, teaching material is an important part of education. Teaching materials can be developed from many learning sources, such as: textbook, flash card, websites, etc. The textbooks are one of learning material commonly used in teaching learning process. It is not surprising that they often become the only materials in the classroom. This fact happens for several reasons. First, textbooks are relatively easy to find and commercially provided. Second, it provides a guide for the learners which offer expected behaviors that they have to perform (Crawford as cited in Richards and Renandya, 2002). Third, textbooks help teachers to prepare the lesson (Brown, 2000). Fourth, they also become a flexible syllabus for teaching and learning 
process in which teachers easily modify based on the students' needs.

Based on the first observation in SD IT UMMI at Salak 3 Street, Dusun Besar, Singaran Pati, Kota Bengkulu, the researcher concluded that in this elementary school seem to ignore school based curriculum (KTSP 2006) as the guidance for teaching English. Some English teachers do not use other sources to develop their own materials based on the standard stated in KTSP. They just use the materials from Let's Make Friends with English without considering some essential factors dealing with students' development and the importance of English as a foreign language.

In short, the entire phenomenon above seems against the theory of teaching English as a foreign language to elementary school students. The materials are not in line with the students' development. Moreover, the importance of English as foreign language seems not to be considered by the teachers in teaching English for elementary school students. Hence, it is important for the research to see whether the English teaching materials relevant to school based curriculum and elementary students' development or not.

Based on the problems above, this research will analyze English teaching material used in SD IT UMMI Kota Bengkulu. The English teaching materials used by English teachers in SD IT UMMI Kota Bengkulu should keep attention on the elementary school students' development. The materials used must consider the content of the textbook and language content (vocabularies) which have to include the relevant topic with school based curriculum (KTSP 2006) and provide the purposeful activities in the term of learning by playing and learning by doing.

Based on the explanation before, the research questions are formulated as follows: Does the English textbook use in second grade students at SD IT UMMI Kota Bengkulu fulfill the criteria of a good textbook?. Is the English textbook used by the second grade students at SD IT UMMI Kota Bengkulu relevant to KTSP curriculum?

From the research questions, this research has two objectives as follow: (1) To find out whether textbook used by SD IT UMMI Kota Bengkulu fulfill the criteria of a good textbook or not. (2) To find out whether the English textbook used by SD IT UMMI Kota Bengkulu relevant to KTSP curriculum or not.

\section{Method}

The researcher used
descriptive evaluative design concerned with the document analysis to describe the condition happened in the English textbook entitled let's make friends with English for the second grade students. Ary et.al (2010) stated that descriptive research is designed to obtain information concerning the current status of phenomena. In this research, the phenomenon was about the evaluation of English textbook which had been published by Erlangga. This research was designed to evaluate a textbook and describe the result of the evaluation.

The data in this study were taken from the English textbook widely used in SD IT UMMI Kota Bengkulu. This was the Let's Make Friends with English. 
The textbook consists of 7 chapters and 103 pages. This research focused on just one book and all of the activities in the textbook in the scope of first semester and second semester.

The checklist given to three teachers in SD IT UMMI Kota Bengkulu and validated by experts in Bengkulu University. Based on the experts' suggestions, the evaluation checklist was written in English and it contained 97 items. The checklist divided into twelve main categories.

In this study, the researcher used some steps to evaluate textbooks. (1) Before conducting the main instrument of this research, the researcher did survey comparison among syllabus, lesson plan, and English textbook used in the second grade at SD IT UMMI Kota Bengkulu. (2) Finding recommendation for adapting instruments. (3) Collecting and gathering related data of the research. (4) Analyzing the data and information gathered from interview instrument and also evaluation checklist instruments.

The instrument is a tool which required to get information. Gay and Airasian (2000) stated that an instrument is a tool which used in collecting data. While, Arikunto (2000) revealed that instrument in collecting data is a tool which used by researchers to help them in collecting data in order to make it more systematic and easy.

In this study, the instruments of this research are: (1) Evaluation checklist: this instrument used to evaluate the content of the textbook used at the school in this research. The researcher used the scale 0-4; $0=$ totally lacking $1=$ poor $2=$ adequate $3=\operatorname{good} 4=$ excellent. This scale used to know how appropriate the textbook used. (2) Interview. In this research, the researcher used semistructured. The items of the questions are more and less five questions. The questions are related to the objective of the research. This interview conducted to the teachers at the school.

The data collected from an English textbook for second grade at SD IT UMMI Kota Bengkulu. This is Let's Make Friends with English. (1) Evaluation checklist. This research used an evaluation checklist to collect the data from the textbook. Evaluation checklist in this research used to find out whether the textbook appropriate to curriculum and good textbook criteria or not. (2) Interview. The interview of this research was semi-structured interview. It is kind of interview which the interviewer has a general idea of where he or she wants the interview to go, and what should come out of it, but the interviewer doesn't enter the interview with a list of pre-determined questions (Nunan, 2003). In this research, the interview in this research is used to know the information deeper and accurately from the English teachers. (3) Documentation. A valuable source of information in qualitative research could be documented. Sugiyono (2008) stated that documentation could be written and picture by someone that could be used to obtain information. In conducting documentation method, the researcher can provide book, syllabus, documents, etc. Documentation method serves to make credible the result of observation or interview.

As this research intends to evaluate textbooks, the checklist 
used to gather data (Ary, et.al. 2010). To get comprehensive results of the data, the checklist is developed from sources comprising criteria from Cunningsworth (1995), Littlejohn in Tomlinson (2011), Nation and Macalister (2010), and Mukundan, et.al (2011)

The calculation of the result of data analysis was given in the textbook. This was done by dividing the total criteria which have been met with the total number of criteria. Then, it multiplied by $100 \%$ to achieve the sum points. The formula of calculation used in the evaluation process is presented as follows.

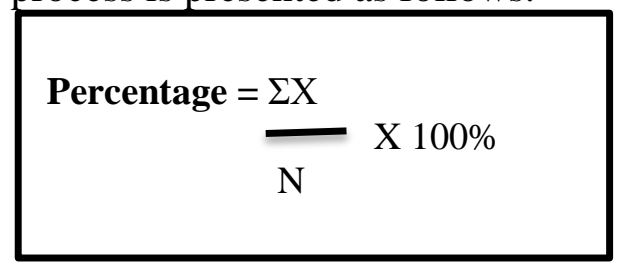

$\Sigma X:$ The total of criteria which were fulfilled by textbook in each aspect.

$\mathrm{N}$ : The total number of criteria in each point.

The formula above used to decide the results of data analysis. The results contained four criteria presented in the following table.

\begin{tabular}{|c|c|}
\hline $\begin{array}{c}\text { Range of } \\
\text { Fulfillment } \\
\text { Score }\end{array}$ & Category \\
\hline $80 \%-100 \%$ & Good \\
\hline $60 \%-79 \%$ & Fair \\
\hline $50 \%-59 \%$ & Sufficient \\
\hline $0-50 \%$ & Poor \\
\hline
\end{tabular}

The conversion of fulfillment average into four proposed categories (Pusat Perbukuan, 2011)

\section{Result and Discussion}

\section{The Relevance of Materials to Criteria of Good Textbook}

\section{General Appearance}

On whether or not the cover of the book is informative and attractive, the results indicate that an extremely high positive response from the raters that support the statement, $66.67 \%$ agree, while only $33.33 \%$ raters disagree with the statement. So, it can be said that the majority of the raters believes that the cover of the textbook in the evaluation checklist is informative and attractive.

a complete consensus on the statements that the font size, orientation page, detailed table of contents, chosen colors, appropriate lesson headings, Reasonable price and glossary are appropriate to the criteria of good textbook. All the raters agree with the statements. This indicates that the raters are completely satisfied with the parts of the book.

Regarding the statement on whether or not the book has a bibliography, the results shown that only $33.33 \%$ rater agree. On the other hand, $66,67 \%$ of the raters either disagreed with the statement and accordingly it can be said that the majority of the English teachers in SD IT UMMI are not satisfied with the bibliography provided in the textbook.

\section{Design and Illustration}

In this part, the researcher concluded that almost all of raters support each statement in design and illustration. It showed that majority in each point above categorized very good or good. The table also shows clearly that most of the raters 
perceive the book as not having consistent artwork.

\section{Accompanying Material}

The results show that there is no suitability of the cassettes that accompany the book. Over 66, 67\% of the raters disagree and only $33.33 \%$ raters agree with the statement. So, it can be said that the cassettes accompanying the textbook are not suitable.

Regarding the CD-ROM that accompanies the book, the table shows that there is no complete consensus on its suitability. Over $100 \%$ of the raters disagree with the statement and none of raters agree. No positive responses are recorded.

On whether or not the posters and flash cards that accompanies the book are informative, the table shows that the results are in favor of the posters and flash cards of the book. Over $66,67 \%$ of them agree with the statement and 33, 33\% disagree.

Furthermore, there are a large percentage of the raters with the statement that the teacher's books that accompany the book are not suitable $100 \%$ of the raters disagree while none of the raters' responses that support the statement

\section{Objectives}

The result shows that there is a complete consensus among the participants on the statement that the book fulfills the general objectives of Teaching English in SD IT UMMI and the book fulfills the general objectives of teaching English based on KTSP curriculum. All of the raters agree with the statement. No one disagrees or strongly disagrees.

Regarding the terminal objectives specified explicitly in the pupil's book, the results show the majority of the raters didn't believe that they are based on some theoretical background, 66, 67\% disagree and only $33,33 \%$ agree.

Concerning the issue of the item no 4-10 in statements above, almost all of the raters support the statement. It means that the raters are completely satisfied with the objectives of the book.

Furthermore, the results show that the majority of the raters didn't support the statement number 11-13 that the textbook is fit to the students' background, students age and students need, almost $100 \%$ raters disagree. None raters did not support the statement.

Different with the textbook seems to be socially acceptable; there is a complete consensus among raters. Over $100 \%$ of the raters agree and none raters did not support that statement.

Finally, the result shows the statement number 16-17 almost all of the raters strongly agree and agree about that.

\section{Topic Contents}

In table 4.5 , over $100 \%$ of the raters agree on the statement number $1-4$ in topic contents. It means that the book has varied topics and appealing to second graders various interests and personalities. And also, the topics encourage students to express their own views, and the book avoids potentially embarrassing or disturbing topics, the results show that all the participants' responses are in favor of the book. On the other hand, the table above shows that raters support the statement that the topics allow students to think critically.

\section{Language Contents}

The result shows that there is a complete positive response on the statement number 1-6 that the book covers the textbook integrate the skill 
well such grammar and vocabulary items appropriate to second graders. Almost all of the raters agree with the statement.

Furthermore, the results show that the majority of the raters disagrees that the presentation of the vocabularies is moving gradually from simple to more complex.

Regarding the issue of whether the authentic task or close to real language situations and book covers the main grammar items appropriate for second graders, the results show that there is a complete agreement. $100 \%$ raters agree and support the statement.

Regarding the issue of whether the book includes adequate materials for teaching vocabulary, the results show that there is a conflict between the raters about the adequacy of the materials for teaching vocabulary. 66. $67 \%$ raters did not support the statement and only 33. $33 \%$ raters agree about that.

However, the majority of the raters supports the statement number 11-12. Over $100 \%$ raters agree and support that statement.

\section{Socio-Cultural Context}

The result shows that all the raters support the statement that the social and cultural contexts in the book are comprehensible; 100\% agree with the statement. No one disagrees or strongly disagree. That can prove that the social and cultural components of the textbook in question are comprehensible.

Furthermore, the table also shows that the percentages of the raters $100 \%$ agree with the statement that the content of the book is free from stereotypical images and information. No one disagrees or strongly disagrees. That indicates that the book is completely free of any stereotypical images or information.

Regarding the issue of whether or not the book can allow students to learn about the inner lives of the characters used in the book, the results show that a high percentage of the raters agree that the student can learn about the inner lives of the characters used in the book. Over $100 \%$ of the raters support the statement.

On whether the textbook in question expresses positive views of ethnic origins, occupations, age groups, social groups and disability or not, a large conflict among the raters can be observed. All of the raters satisfied with social and cultural contexts of the textbook.

\section{Language Skill}

The result above shows the percentage of the raters supporting that the four skills are adequately covered. It means that $66.67 \%$ agree with the statement while $33.33 \%$ of the raters are against it.

On whether there is material for integrated skills, work or not. The results show that there is a conflict between the raters about that. $33.33 \%$ raters agree with the statement. On the other hand, $66.67 \%$ of the raters disagree with the statement.

Regarding the listening material of the book in question, the results show that the majority of the raters disagree about the listening material is well recorded, as authentic as possible, and accompanied by background information, questions and activities. None raters agree and strongly agree with the statement.

The results of statement number 4-6 above show the largest percentage. Over $100 \%$ raters 
support the statements and none raters disagree about the statements.

\section{Teach ability}

The result shows that a high percentage of the raters did not support the statement that the book helps teachers to minimize their preparation time, only $33.33 \%$ of the raters agree. Over $66.67 \%$ of the raters disagree with the statement.

On whether or not the book helps teachers exploit the activities to meet the students' expectations, the table shows again a large agreement. Over $100 \%$ of the raters perceive that the book helps teachers exploit the activities to meet the students' expectations. None of the raters disagree with the statement.

Regarding the issue of whether the book helps teachers cater for mixed ability students and classes of different sizes, the results show that most of the raters support the statement, $66.67 \%$ agree. On the other hand, only $33.33 \%$ raters do not support the statement.

\section{Flexibility}

The result shows that the majority of the raters supports the statement about whether or not the book is appealing and useful to the students, caters for different levels of formality, and provides opportunity for teachers and students to localize activities. Almost all of raters agree about statements.

In the terms of flexibility, only the book caters for different preferred learning styles that indicate that a high percentage of the participants do not support the statement. Over $66.67 \%$ disagree with the statement.

\section{Teaching Methods}

In teaching methods, the result shows that the English teacher at SD IT UMMI Kota Bengkulu used the best methods. It is appropriate with KTSP (Kurikulum Tingkat Satuan Pendidikan). It means that an extremely high percentage of the raters supports the statement about the teaching methods used in the book are the latest in the field, "student-centered" allow students to talk more than teachers and allow various class activities.

\section{Practice and Test}

The result shows that there is a complete agreement on the statement number 1-5 that the textbook have appropriate practice and test. Almost all of the raters agree with the statement.

Furthermore, the results show that the majority of the raters (66. $67 \%$ ) disagree that the book provides periodical revisions for diagnostic purposes.

However, the majority of the raters supports the statement number $7-10$. Over $100 \%$ raters agree and satisfied about the statements.

Regarding the issue of whether the review exercises sufficient, the balance between free and controlled exercises, the results show that $100 \%$ raters disagree and did not support the statement.

The table above shows that an extreme percentage of the raters support the statement number 13-19. Almost all of raters agree and strongly agree about the practice and test of the textbook used at SD IT UMMI Kota Bengkulu. And, the raters only did not support the textbook provides warm-up introductory activities. 


\section{The Relevance of Textbook to KTSP}

In analyzing the course book, the researcher was assisted by some English teachers. They were asked the interview and to fill in the checklist of the material evaluation. Here is the interview with the teacher about students' ability in learning English.

Menurut saya, kemampuan siswa dalam berbahasa inggris sudah cukup baik hanya saja sangat disayangkan banyak para siswa yang kurang senang belajar bahasa Inggris, karena menganggap mata pelajaran ini menjadi kendala disebabkan tidak digunakan dalam komunikasi sehari harinya. Sebagian para siswa merasa jenuh, bahkan setres bila mengikuti pelajaran ini, apalagi jika pembelajaran tidak dibarengi dengan latihan yang menarik dan menyenangkan (U.N: 09 Agustus 2017).

In my opinion, the ability of the students in English has been already good enough. Unfortunately, most students less pleased to learn English, because they consider these subjects are constraints due to not being used daily. Most students feel saturated and stress to learn English, if the exercises is not interesting and fun. (U.N: 09 August 2017).

The information above informed that the second grade students at SD IT UMMI Kota Bengkulu needed interesting material to make them enjoy learning English.

Furthermore, based on the result of the interview and checklist, the researcher analyzed the Let's Make Friends with English course book which the most relevant to the KTSP. It is necessary to get the real description of the uses of this book in the elementary schools at SD IT UMMI Kota Bengkulu. These data related the researcher's answer :

Menurut saya, buku yang kami gunakan sudah sesuai dengan kurikulum yang ada. Tapi sangat disayangkan sekali, kami tidak menerima materi pelengkap yang menyertai buku, seperti $C D$ ROM, kaset ataupun soft file untuk listening. Selain itu, kami juga tidak membunyai buku khusus untuk guru. Terkadang kami kesulitan untuk memberikan materi listening kepada siswa. Jadi terkadang kami mengarang materi sendiri atau jika sempat kami mencari sumber lain (U.M: 09 Agustus 2017).

According to me, the book that we use is in compliance with the existing curriculum. But, we do not receive complementary accompanying material of the book, such as a CD-ROM, tape or soft files for listening. In addition, we also do not have a special book for teachers. Sometimes we are hard-pressed to provide the material in listening to the students. So, we create new materials or looking for other sources (U.M: 09 August 2017).

It's meant that the teacher must be creative and innovative to create new materials. These data related the researcher's answer statement about the uses of Let's Make Friends with English course book at SD IT UMMI Kota Bengkulu.

Materi yang digunakan belum mencakup semua skill, karna untuk listening tidak ada materi pendukung yang bisa kami gunakan. Buku yang kami 
gunakan tidak dilengkapi dengan caset ataupun CD. Jadi kami sedikit kesulitan untuk skill listening. (U.E: 09 Agustus 2017)

The material used is not yet cover all the skill, because there is no supporting materials for listening that we could use. The textbook is not equipped with a cassette or CD. So, we were a little troubled for the skill of listening. (U.E: 09 August 2017)

It's related to some components of the checklist below. Each of them described as follows:

\section{Listening}

Regarding the listening material of the book in a statement, the results show that the majority of the raters disagree about the listening material is well recorded, as authentic as possible, and accompanied by background information, questions and activities. None raters agree and strongly agree with the statement.

\section{Speaking}

The statement shows the percentage of the raters supporting that there are sufficient materials for spoken English (e.g. Dialogues, role plays, etc.). It means that $33.33 \%$ of the raters strongly agree and $66.67 \%$ agree with the statement.

\section{Reading}

On whether there are sufficient reading material or not. The results show that $100 \%$ raters agree about that. None strongly disagrees and disagree with the statement.

\section{Writing}

The results of statement writing activities are suitable in terms of length, degree of accuracy, and amount of guidance show the largest percentage. Over $100 \%$ raters support the statements and none raters disagree about the statements.

\section{DISCUSSION}

In the cumulative textbook evaluation checklist, percent of agreement of the raters amounts $84.32 \%$ it categorized good agreement. The lowest agreement of the raters' amount $80.00 \%$ and the highest agreement of the raters amount $100 \%$.

Based on the data described in the result, some research findings should be discussed. The discussion comprised two items related to the relevance of the materials to the criteria of good textbooks and to curriculum or SK and $\mathrm{KD}$ in the Let's Make Friends with English. These research findings are discussed below:

The Relevance of Materials to Criteria of Good Textbooks General Appearance

Acknowledging the importance of textbook attractiveness, the survey sought to evaluate the second grade text from that perspective. Informed by a variety of studies, the criteria for determining attractiveness were 1) cover; 2) font size; 3) orientation page; 4) detailed table of contents; 5) chosen colors; 6) appropriate lesson headings; and 7) Reasonable price; 8) appropriate glossary 9) comprehensive bibliography.

As noted in the result, eight of the nine evaluative criteria in the textbook were deemed appropriate. Only as pertains to bibliography did a comparatively significant percentage of the raters find substantial room for improvement. It should be noted at this stage, however, that this is the perception of the textbook which teachers, not students, have. Nevertheless, their perception is uniquely important. Not 
only because it is informed by experience, but also they are the ones who will be ultimately responsible for teaching through this book and, indeed, of devising the ways and means by which to incite greater student interest and curiosity in the subject at hand.

\section{Design and Illustration}

As indicated before, the results for this category were good. It is quite important to note that a significant percentage of the raters had positive opinions regarding the textbook illustrations. This is considering that illustrations serve the purpose of clarifying complexities and of stimulating both interest and creativity. Sheldon (1988) suggests having "an optimum density and mix of text and graphical materials on each page". He also emphasizes the importance of having colorful and appealing artwork.

\section{Accompanying Material}

The raters tended towards the opinion that the accompanying material was not appropriate for the textbook in statements. It is important to note here that this particular level of evaluation does not speak for the textbook itself, but only for its accompanying material and, even then, the appropriateness of that material within the context of the textbook itself. Consequently, that the accompanying material was deemed appropriate does not mean that the textbook itself is appropriate or, at least, that the appropriateness of the textbook cannot be judged on the basis of the responses to this question-set.

\section{Objectives}

As indicated in the result, opinions tended towards the positive. According to the majority of the raters, the textbook covered all of the components in checklist and quite effectively functioned as a teaching and learning aid. That does not mean to imply that the raters did not identify any area where there was room for improvement, as they did. None the raters said that the materials for teaching pronunciation were not satisfactory. However, it is important to note that this was the only area over which critical opinions were voiced and, in general, the learning components were positively evaluated.

\section{Socio-Cultural Context}

In general, the responses to the statements about this category have been varied and mixed. As regards the first statement, whether or not the socio-cultural context was suitable and understandable. This means that the textbook's references were drawn from world views and socio-cultural environments with which the students were familiar. As for the second statement, pertaining to whether or not the textbook promoted stereotypes, the participants unanimously maintained that it did not.

\section{Language Skill}

Generally, the results, as evidenced in the above table are balanced. The textbook is not optimally designed to equally satisfy all the required skills, but it does, nevertheless, generally satisfy the requirements of English skills development. The four skills are, according to most of the raters, satisfactorily covered in the textbook. They are not, however, given equal weight. The focus tends to be significantly more on writing and reading, than on listening and conversation skills. Prior to criticizing this particular shortcoming, it is necessary to point 
out two facts. The first is that the textbook in the statement is aimed towards second grade students in SD IT UMMI Kota Bengkulu, with the implication being that this group is still at the stage where they need to grasp a degree of mastery in vocabulary, grammar and writing. They need to grasp the language before they can engage in conversation. This does not mean that conversation is ignored as it is not. Instead, it gives less weight than are reading and writing skills.

\section{Teaching ability}

In general, the greater majority of the raters opined that the textbook in question greatly facilitated the ability of teachers to prepare their lessons and, indeed, to satisfy their objective of effective teaching. The implication here is that the textbook functions as a very good guide for teaching English to second grade students in SD IT UMMI Kota Bengkulu.

\section{Flexibility}

As illustrated in the result, four questions were asked and the results tended to be mixed. Regarding the issues of whether or not the textbook was useful and appealing to students and whether or not it helps localize the activities of both students and teachers, the results were positive and definitely indicated that the textbook contributed significantly to the satisfaction of these two functions.

\section{Teaching Methods}

As indicated before, the results tended towards the negative, strongly suggesting the imperatives of revision. Not only did the majority believe that the textbook unfolded in accordance with outmoded teaching and learning strategies but an overwhelming majority of raters maintained that the book is teacher centered, does not allow for student participation and quite effectively constraints any, and all, opportunities for class activities which would promote the teaching and learning of English.

\section{Practice and Test}

As noted before, the participants tend towards a largely positive view of the textbook as a tool for practice and test. The great majority of raters have positive views as regards the attention the textbook pays to practice and test, maintaining that the exercises contained therein are varied, clearly explained and representative of the preceding lessons.

\section{The Relevance of Textbook to KTSP \\ Listening}

As listening activities provide authentic input to the This textbook has generally provided appropriate listening tasks in each unit. There, listening was presented through "Listening" section. Listening tasks, serving as an input, offered different spoken texts for learners in the form of dialogues and monologues. Though providing input in each unit, listening tasks were mostly spoken by the teacher. It therefore did not provide listening tasks in the form of recording or video. This was not interesting and appealing for the learners as it did not portray the real characters in each dialogue. Also, the conversation would not be authentic since it was only spoken by the teacher.

\section{Speaking}

Basically, speaking activities should promote the reality that the learners would face in real life situation. First, learners should be made aware that speaking can be 
uncertain in some ways. The conversation in daily life can be unpredictable. Second, learners must also understand the way to run the conversation in an appropriate way. In other words, they need to acquire the strategy of overcoming breakdown in communication. These aspects are said to be lacking in most EFL textbooks (Cunningsworth, 1995).

Simple Dialogue, Selfintroduction, Classroom Language, Role play and Talk about food, hobby, and family are activities to encourage students to be active and speak. This textbook contained different kinds of speaking activity, like an interview, telling about their self, animals and hobby.

\section{Reading}

Realizing the importance of reading tasks as an input for the students, the activities should not only promote acquisition by containing language slightly beyond their proficiency level but also provide a favorable condition to the students. This is seen as a beneficial thing to do it will foster their motivation in the teaching and learning process. To do so, the texts and activities presented in each unit should cater their interests.

There were various reading texts in the textbook which familiarized young learners to the real life. This book also presented a word, phrases, simple sentence, and simple text as reading materials. Reading skills are taught from word, phrase, and followed by simple sentence and a short text.

\section{Writing}

In general, writing activities in the textbook require the students to produce something based on the given model. The emphasis of this will be on the teaching writing skills, strategies, and processes in a sequential way (Ferris and Hedgecock, 2005). This is realized through many types of activities presenting on the textbook. These consist of controlled, guided, and free writing activities such as filling the gaps, dictation, filling in forms, and free writing.

The writing activities of this textbook ware generally appropriate to young learners' level. It presented various of activity in a writing activity. Generally, the activity of writing that was presented in this book is good and suitable to the young learners' need

\section{Conclusion}

\section{The Relevance of Textbook to Criteria of Good Textbook}

The result of the finding and discussion shows that $88.90 \%$ of the book meets the requirements of a criteria good textbook in terms of general appearance. $90.90 \%$ of the book meets the requirements of a criteria good textbook in terms of design and organization. $25.00 \%$ of the book meets the requirements of a criteria good textbook in terms of accompanying materials, $70.60 \%$ of the book meets the requirements of a criteria good textbook in terms of objectives, $100 \%$ of the book meets the requirements of a criteria good textbook in terms of topics appropriateness, $83.30 \%$ of the book meets the requirements of a criteria good textbook in terms of learning component, $100 \%$ of the book meets the requirements of a criteria good textbook in terms of socio-cultural, $66.70 \%$ of the book meets the requirements of a criteria good textbook in terms of skill development, $66.70 \%$ of the book meets the requirements of a criteria 
good textbook in terms of teach ability, $75.00 \%$ of the book meets the requirements of a criteria good textbook in terms of flexibility, $91.70 \%$ of the book meets the requirements of a criteria good textbook in terms of teaching methods and $78.90 \%$ of the book meets the requirements of a criteria good textbook in terms of Practice and test.

The English textbook entitled "Let's Make Friends with English (Student's Book)" fulfilled 78.14\% criteria of good textbook adapted from some experts. According to the percentage of fulfillment, it can be concluded that the textbook was categorized as fair in fulfilling the requirements of good textbook criteria. It means that teachers can use the textbook as a reference to teach the second graders of elementary school, yet it needed a lot of improvements particularly in terms of accompanying materials.

The Relevance of Textbook to KTSP

The objective of this research is to evaluate the Let's make friends with English Course book that is relevant to the learning objectives in the KTSP Curriculum. Based on the objective of the study, this book is relevant to the learning objectives in KTSP Curriculum in writing, speaking, and reading because they can cover the learning objectives in writing, speaking and reading, but the activities in the listening can be said irrelevant because they cannot cover the learning objectives in listening.

\section{References}

Arikunto, Suharsimi (2000). Prosedur Penelitian Suatu
Pendekatan

Praktek,

Jakarta: Rineka Cipta.

Bednarek, Monika (2008).

Emotion Talk across

Corpora. Palgrave.

Brown, H.D. (2000). Principles of language learning and teaching (4thed). New York : Addison Wesley Longman.

Bybee, J. and S. Fleishman (1995), Modality in Grammar and Discourse (Typologial Studies in Language)", Amsterdam/Philadelphia: John Benjamins Publishing Company.

Byrd, P. (2001). Textbooks : Evaluation for Selection and Analysis for Implementation. In CelceMurcia, M. Teaching English as a second or foreign language ( $3 \mathrm{rd} \mathrm{ed}$ ). US : Heinle \& Heinle.

Cunningsworth, A. (1995). Choosing Your Coursebooks. Oxford : Maxmillian Heienman ELT. 173

Fairclough N. (2003). Analyzing Discourse and Text: Textual Analysis for Social Research. London: Routledge.

Ferris, Dana R and Hedgcock, John S (2005). Teaching ESL Composition "purpose, process and practice. Mahwah, New Jersey: Lawrence Erlbaum Associate. 
Garinger, D. Textbook Evaluation. Retrieved July 14, 2007, from

http://www.teflwebj.org/v1n 1/garinger.html

Gay and Airasian (2000). Educational Reasearch "Competencies for Analysis and Applications. United States of Amerika: Pearson Education, Inc.

Graves, K. (2000). Designing Language Courses. Canada: Newbury House.

Hedges, T. (2000). Teaching and Learning in the Second Language Classroom. Oxford: Oxford University Press.

Hunston, S., \& Thompson, G. (Eds.) (2000). Evaluation in Text: Authorial Stance and the Construction of Discourse. Oxford: Oxford University Press.

Hyland, K.(2002). Teaching and researching writing. London : Pearson Education.

Littlejohn, A. (2011). The analysis of language teaching materials : inside the Trojan horse. In Tomlinson, B. (Ed). Materials development in language teaching. Cambridge : Cambridge University Press.

Masuhara, H. (2013). Materials and methods in ELT: A teacher's guide (3rded). West Sussex : Willey-Blackwell.
McGrath, I. (2002). Materials Evaluation and Design for Language Teaching. Edinburgh: Edinburgh University Press.

Mukundan, J., Nimehchisalem, V, \& Hajimohammadi, R. (2011). Developing an English language textbook evaluation checklist : A focus group discussion. International Journal of Humanities and Social Science, 1 (12), 100-106.

Nation, I.S.P \& Macalister, Jhon. (2010). Language curriculum design. New York: Routledge.

Nunan, D. (2003). Practical English language teaching. Singapore: McGraw Hill

Park, E. (2004). A Study on English Textbook Used in a Technical High School: Issues in EFL. (online), Vol.3

(http://TEFLIN.journal.ac.id ) accessed on August, 2017)

Patton, M.Q. (2002). Qualitative Research and Evaluation Methods. California: Sage Publications.

Piaget, J. (1980). Six Psychological Studies. New York:

Vintage.

Print, M. (1993). Curriculum Development and Design (2nd Ed). Sydney : Unwin Pty.Ltd. 
Richards, J.C. (2001). Curriculum development in language teaching. Cambridge: Cambridge University Press.

Richards, J.C., \& Renandya, W.A. (2002). Methodology in language teaching: An Anthology of current practice. Cambridge: Cambridge University Press.

Richards, J.C. (2013). Curriculum approaches in language teaching: forward, central, and backward design. RELC Journal 44(1) 5-33.

Richards, J.C. \& Rodgers, T.(2001). Approaches and methods in language teaching. Cambridge : Cambridge University Press.

Sheldon, L. (1988). Evaluating ELT Textbooks and Materials. English Language Teaching Journal, 42(4), 237-246.

Sugiyono. (2009). Metode Penelitian Kuantitatif, Kualitatif dan $R$ $\& D$.Bandung: Alfabeta.

Tarigan, H. Guntur (2010). Telaah Buku Teks Bahasa Indonesia. Bandung: Angkasa.

Thein, N. (2006) Evaluating the Suitability and Effectiveness of Three English Coursebooks at Myanmar Institute of Technology. Unpublished MA thesis, University of Thailand. Thailand.
Tomlinson, B. (1998). Materials Development in Language Teaching. Cambridge : Cambridge University Press.

Tomlinson, B., et.al (2001) EFL courses for adults. ELT Journal 55(1): 80-101.

Tomlinson, B. (2003) Materials Evaluation. In Tomlinson, B. (ed) (2003) Developing Materials for Language Teaching. London and New York: Continuum.

Tomlinson, B. (2012). Principles and Procedures of Materials Development. N. Harwood (ed.), 81-108.

Tu'eimah, R. A. (1985). A Guide for Preparing Arabic Language Teaching Programs. Arabic Language Institute. Umm Al-Qura University, Makkah, Saudi Arabia.

Ur, P. (1996). A Course in Language Teaching : practice and theory. Cambridge : Cambridge University Press.

Ur, P. (2009). A Course in Language Teaching : practice and theory. Cambridge : Cambridge University Press.

Widdowson, H. G. (1983) . Learning Purpose and Language Use. Oxford: Oxford University Press. 